\title{
Role, Services of Project Management Consultancy in Construction Projects \& the Audit Process
}

\author{
Atul R Nikumbh ${ }^{1}$, Dr. S.S. Pimplikar ${ }^{2}$ \\ ${ }^{I}$ P.G. Student - ME (Construction \& Management), ${ }^{2}$ Prof \& Head of Dept. of Civil Engineering, \\ MAEER'S Maharashtra Institute of Technology; Pune, Pune university, India.
}

\begin{abstract}
To Manage the various kind of construction projects requires an know-how with organizations and a thorough body of knowledge. The project Management consultancy has characteristic of Knowledge, Performance \& Inter-personal Skills. The purpose of this paper is to provide the analysis or breakdown of various services \&Role of Project Management Consultancy and study the Problems faced by PMC for executing the project. Project Management Consultancy have versatile role in various construction projects and provides the various services from Initiation to Handing over of projects. The customer / client's requirements is very essential during the project life cycle and all is looking after by Project Management consultancy during their services Project Management Consultancy (PMC) provides one of the helpful management solution to enhance and growth the efficiency and outcome of a project in construction. A research is carried out to study the Role. Services and Operating Processes provided by the Project Management Consultancy (PMC) in construction projects, identify the methods of selection of the Project Management Consultancy by the clients, to identify the problems faced by Project Management Consultancy's in project implementation, and to determine the level of Importance \& satisfaction regarding the services provided by the Project Management Consultancy with respective all stakeholders viz Client, Consultant, contractors, etc.
\end{abstract}

Keywords: Importance \& Satisfaction of PMC's Services, Knowledge, Project Management Consultancy $(P M C)$, Role \&Services of PMC, Standard Operating Processes.

\section{INTRODUCTION:}

The construction industry in India has expanded very fast with the construction of new projects. Due to the rapid growth in the construction industry, the services provided by the Consultancy need to be enhanced in terms of performance and excellence of work to meet the construction project goals and objective and also the Participant (stakeholder) satisfaction. Efficiency in Management is needed to gain a higher level in competitiveness The Project Management Consultancy has a ample variety of roles to perform during the construction process therefore it is significant to fully figure out Project Management Consultancy and influence through their services in terms of importance and satisfaction of the same.

The paper focuses on research dealing with study of PMC services and measures their performance in terms of importance \& satisfaction along with their audit processes. A number of questionnaires were circulated to the respondents comprising of Project Engineers, Project Managers, Architect and client's representatives. Clients Interview was also conducted. The collected information / data is analyzed using the method of average index. From the study, it was observed that the scope of services provided by PMC is categorized in three stages namely the pre-construction, construction stage and the post-construction stage.

Paper also broadly highlights the case study for research of dealing the Mega Industrial Projects by PMC through their role and responsibility during project life cycle from Project Concept Phase -Development Phase-Execution Phase- Transfer Phase. In all phases PMC manage the project by various services like Conceptual \& Feasibility Study, Planning \&Scheduling, Managing the Meetings, Tendering \&Procurement, Estimating and Budgeting, Contract and legal considerations, Monitor and Controlling, Regular Status Reporting, Change order \&Cost Control, Invoicing \&Payment Certification, Quality Assurance \&Control, Directing \&Expediting, Testing \&Commissioning ,Punch Listing \& Handing Over, etc.

PMC is selected mainly through previous work performed in past projects, reputation of firms, and Calling for tenders. The problems faced by the PMC are Ambiguous project statement by Clients, Slow decisions by owner, unclear work procedure, and unrealistic imposed duration. The level of stakeholders satisfaction regarding PMC services are contract \& Legal considerations, Planning \&Scheduling (Time Management), managing the meetings shows Satisfied .Project Management Consultancy (PMC) is one of the Management Solutions to develop the effectiveness of a project in construction. The use of these services has been increased construction industry around the world. This consultancy plays a comprehensive and cohesive part in the construction project, and is usually involved in the project from the project's beginning to its end. 
II. OVER VIEW OF CONSTRUCTION INDUSTRY:

Today, India is the second fastest growing economy in the world. The Indian construction industry is an integral part of the economy and a conduit for a substantial part of its development investment, is poised for growth on account of industrialization, urbanization, economic development and people's rising expectations for improved quality of living. In India, construction is the second largest economic activity after agriculture.

\section{CONSTRUCTION INDUSTRY SEGMENTS \& INDIA'S ECONOMIC GROWTH:}

If we study the India's economic growth, $10-15 \%$ of GDP share is belonging to construction industry and over all GDP growth increasing by $8 \%$ and expected growth in next year is $11 \%$ as shown in fig-01.Construction segments both real estate as well as infrastructure, the Project Management Consultancy's involvement is being introduced as younger generation.

\section{Expected growth in the next few years}

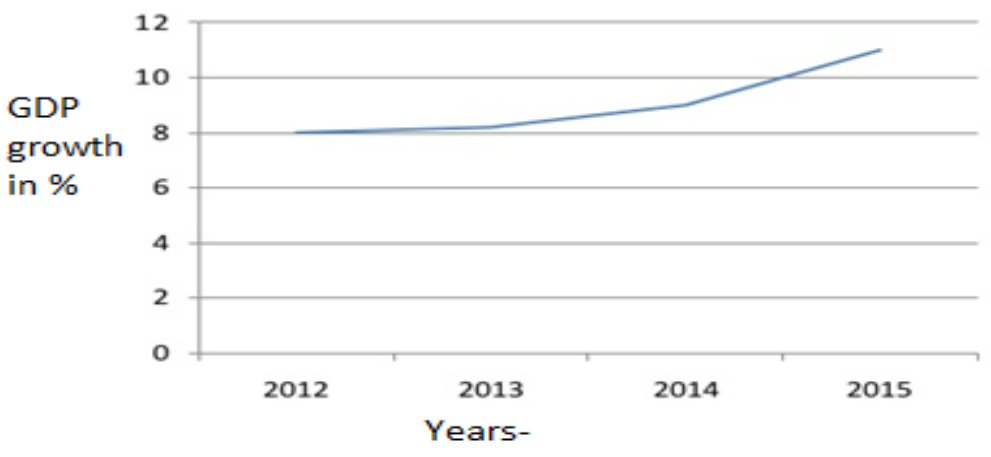

Fig-01 India Economy Growth

\section{OBJECTIVE OF STUDY:}

$\Delta$ To identify the different roles and responsibilities of PMC and to study the various services they provides for project management.

$\Delta$ To identify the problems faced by Project Management Consultants in project implementation of industrial construction and recommendation solutions.

$\Delta$ To examine the Standard Operating Processes adopted by a Project Management Consultancy firm working in industrial construction domain for more than 40 years and study the process of internal audit.

$\Delta$ To measure the performance of PMC Services by a weighted point score average rating system devised particularly offered in industrial construction for project management Consultancy.( To determine the level of Importance\& satisfaction of all regarding the services provided by the Project Management Consultant)

\section{SCOPE OF STUDY:}

The study is limited to project management of construction projects, mainly industrial projects undertaken by Project Management Consultants in India. This research was carried out based on data collected from the questionnaires. The research focuses on the projectsusing Project Management Consultant (PMC) services. It focused on types of services provided by Project Management Consultants of the project.

\section{LITERATURE REVIEW:}

Project management consultancy services are not a substitute for top managements own reporting structure. They are the independent sources of objective information that prudent management demands from a situation involving risk (Philip, 2000).

The Alexander Hamilton Institute (1984) had realized the necessity of consultancy to be applied in construction industry. Many projects are completed without any formal project consultancy practices. These projects are often plagued with delays and cost overruns. The main point is not just completing a project, but completing it correctly. If the projects end with massive cost overruns or constant delays, you are probably not getting a maximum return on investment from all the time and effort you and your firm expended. Thus, in order to understand project management, you must first recognize what a project is (Harold, 2004). 


\section{Definition OF Project Management\& Projects: \\ What is Project Management?}

In the view of the Project Management Institute ("PMI"), the definition of Project Management is:

"The art of directing and coordinating human and material resources throughout the life of a project by using modern management techniques to achieve predetermined objectives of scope, cost, time, quality and participant [stakeholder] satisfaction."

Special attention should be given to the word "satisfaction". PMI believes that this is a key ingredient of successful projects. That is to say, a successful project is one in which all the stakeholders feel equally good about the end results.

Even more basic to the term project management is the word Project itself. As noted earlier, unlike their relatively steady state of an on-going enterprise, a project has some distinctive characteristics of its own. Generically speaking, a project seems to be "Any assignment which will end when a goal is reached."

The point is that a project is not an on-going activity. Rather, it is an undertaking that ends with a specific accomplishment and the product or end result is a distinguishing characteristic.

In practice, the work to be accomplished on most projects is constrained by the limited availability of resources. Therefore, again in PMI's view:

"A project is any undertaking with a defined starting point and defined objectives by which completion is identified. In practice most projects depend on finite or limited resources by which the objectives are to be accomplished".

The function of project management is, of course, the whole process of managing a project.

\section{PROJECT MANAGEMENT CONSUlTANT:}

There is no specific definition of project Consultancy. Most definition described management Consultancy by their roles and responsibility and services that they provide using tools and skills they have in delivering a task assigned by the client or the owner of the project (Dzulkarnaen, 2005). There is some confusion with the terms to describe the word Consultancy.

Some of the contractors do some consulting, and some of the Consultancy also acts as contractors. This happens because the roles and responsibilities of Consultancy's is very wide and depends on their skills and experiences. Consultation is happening if the clients seek expert knowledge or some opinions on some engineering problems or anything that involves engineering matters. Consultation maybe brief or extended which some involve only few hours of time, with the clients sitting across the desk of the Consultancy. Other consultation may require traveling, some period a substantial portion of a Consultancy's time over a period of several months, and repeated presentations and discussions with the client (Maxwell, 1982).

\section{ROLES AND RESPONSIBILITY OF PROJECT MANAGEMENT CONSULTANT:}

Table 01 shows the roles and responsibility for the Project Management Consultant of the project at different stages of construction.

Table: 01Role in Various Phases

\begin{tabular}{|l|l|l}
\hline 1.Pre-Construction Phase : & 2.Construction Phase : & 3.Post- Construction Phase : \\
Project definition & Appointment of contractors & Package closure - Technical \& \\
Project administration & Planning management & commercial \\
Appointment of architect and consultants & Cost management & Final cost report \\
Design management & Site management & \\
& Quality control & \\
& Safety management & \\
& Co-ordination with client, architect and & \\
& other consultants & \\
& Procurement management & \\
\hline
\end{tabular}

\section{METHODOLOGY OF STUDY:}

The data of this research was collected from different sources. Literature and theoretical reviews have been taken from books, articles and papers to describe main concepts about consultant service management in construction project.

The main methods are descriptive, explanatory and quantitative. The description will start by providing information about the current situation on the field of the construction industry in India and the roles of consultants in construction project industry. The quantitative is done by collecting data from field /site and by standardized questionnaires from the case study (role of project management consultancy in construction project) which are distributed to the client, contractor and supplier, and then all outcome data of the survey is analyzed. 


\section{CASE STUDY:}

Project Management Consultancy manages the Mega Industrial Project in Maharashtra, India. Project land area of 92.00 Acre and proposed Industrial Buildings are 8 No ( $16.50 \mathrm{Lac}$ sqft ) space with supporting utilities building, other services like fire fighting, etc and whole project is bifurcated in to 3Phases with allied infra works

\section{QUESTIONNAIRE SURVEY:}

Construction industry survey was carried for studying the Project Management Consultants services . In order to distribute the questionnaire to the required respondant, the questionnaire was pre-tested. A pilot questionnaire was drafted from the findings of literature to develop the final questionnaire. The purpose of the pilot is to check that the design of the questionnaire works in practice, and to identify and amend problematic questions and refine the questionnaire. The questionnaire was first test with different groups, including Engineers, researchers, colleagues who are related to the disciplines.

A total of 42 questionnaires were distributed to the potential respondents in India, which included the clients, contractors, architects, other consultants, \& PMC firms, etc

The questionnaire survey was divided into several major sections which were a guide to filling up the form; demographics (general information of the respondent and the organization); services provided by Project management Consultant; level of important and level of satisfaction of services provided by PMC.

\section{DATA ANALYSIS:}

All the data was collected from the questionnaires and analyzed in two steps or methods. These are Frequency and Average Index. Frequency analysis is used as preliminary analysis. This method will show the frequency and the percentage. The frequencies are represented in the form of tables and charts.

In analyzing the data, As per table 02 , the following assumed values will be considered for responses on the degree of importance of services that should be provided by Project Management Consultant (PMC) and on the degree of satisfaction of services provided by Project Management Consultant (PMC).

Table: 02 Scale Range (1 - 5) for Importance \& Satisfaction

\begin{tabular}{|l|c|l|l|c|}
\hline \multicolumn{1}{|c|}{ Key Answer } & Marks & & \multicolumn{1}{c|}{ Key Answer } & Marks \\
\hline Not important & 1 & & Strongly Disagree & 1 \\
\hline Less Important & 2 & & Disagree & 2 \\
\hline Moderately & 3 & & Neutral/Not sure & 3 \\
\hline Important & 4 & & Agree & 4 \\
\hline Very important & 5 & & Strongly agree & 5 \\
\hline
\end{tabular}

\section{XIV.I Average Index :}

The data will be collected on both the degree of importance and degree of satisfaction of services provided by the Project Management Consultant (PMC) will be tabulated based on the number of responses for each category of degree of importance and degree of satisfaction. Based on the frequency analyses the average index will be calculated to determine the ranking of each constructability principles being considered.

The average index is calculated as follows (ahmaidi, 2011).

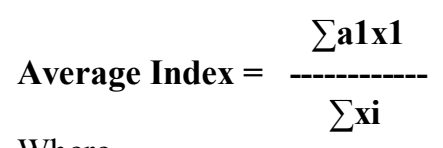

Where,

a1 $=$ constant expressing the weight given to $i$, where $i=1,2,3,4,5$

$\mathrm{xi}=$ variable expressing the frequency of response according to $\mathrm{a}$.

Based on the assumed values stated earlier,

$\mathrm{x} 1=$ frequency of the "Not Important" and corresponding to $\mathrm{a} 1=1$,

$\mathrm{x} 2=$ frequency of the "Less Important" and corresponding to $\mathrm{a} 2=2$,

$\mathrm{x} 3$ = frequency of the "moderately important" and corresponding to $\mathrm{a} 3=3$,

$\mathrm{x} 4=$ frequency of the "Important" and corresponding to $\mathrm{a} 4=4$,

$\mathrm{x} 5=$ frequency of the "Very Important" and corresponding to a $5=5$.

In order to determine the degree of importance or satisfaction of the services provided by the Project management Consultant in this study the classification of the rating scale proposed by ahmaidi (2011) have been used. The classification of the rating scales are as follows:

\footnotetext{
"Not important": $1.00 \leq$ Average Index $<1.50$.
} 
- $\quad$ "Less Important": $1.50 \leq$ Average Index $<2.50$.

- $\quad$ "Moderately important": $2.50 \leq$ Average Index $<3.50$.

- $\quad$ "Important": $3.50 \leq$ Average Index $<4.50$.

- $\quad$ "Very important": $4.50 \leq$ Average Index $<5.00$.

i. Introduction :

XIV. ANAlysis \& ReSUlts:

Forty Two sets of questionnaires were used to obtain data from the parties involved in Project management Consultant. The parties who responded to the questionnaires included the Client, Contractors, Project Management Consultant architects, and representative of them project engineers, project managers, client's representative and the consultants. The results and analysis are divided into Five sections: Sections A, $\mathrm{B}, \mathrm{C}, \mathrm{D}$ and $\mathrm{E}$.

All the collected data from the questionnaires were analyzed in frequency analysis as preliminary analysis. This method shows the frequency and the percentages. The frequencies are then represented in the form of graphs/ charts.

From the framework, the author has conducted an industry survey using the questionnaires to measure the level of importance of each service listed in the case study. Table03below shows the framework of services that should be provided by the Project Management Consultant in construction industry.

The results and analysis from the questionnaire (section A and section D) illustrates as demographics and as services provided by PMC.

Table:03 List of various Services \& Description

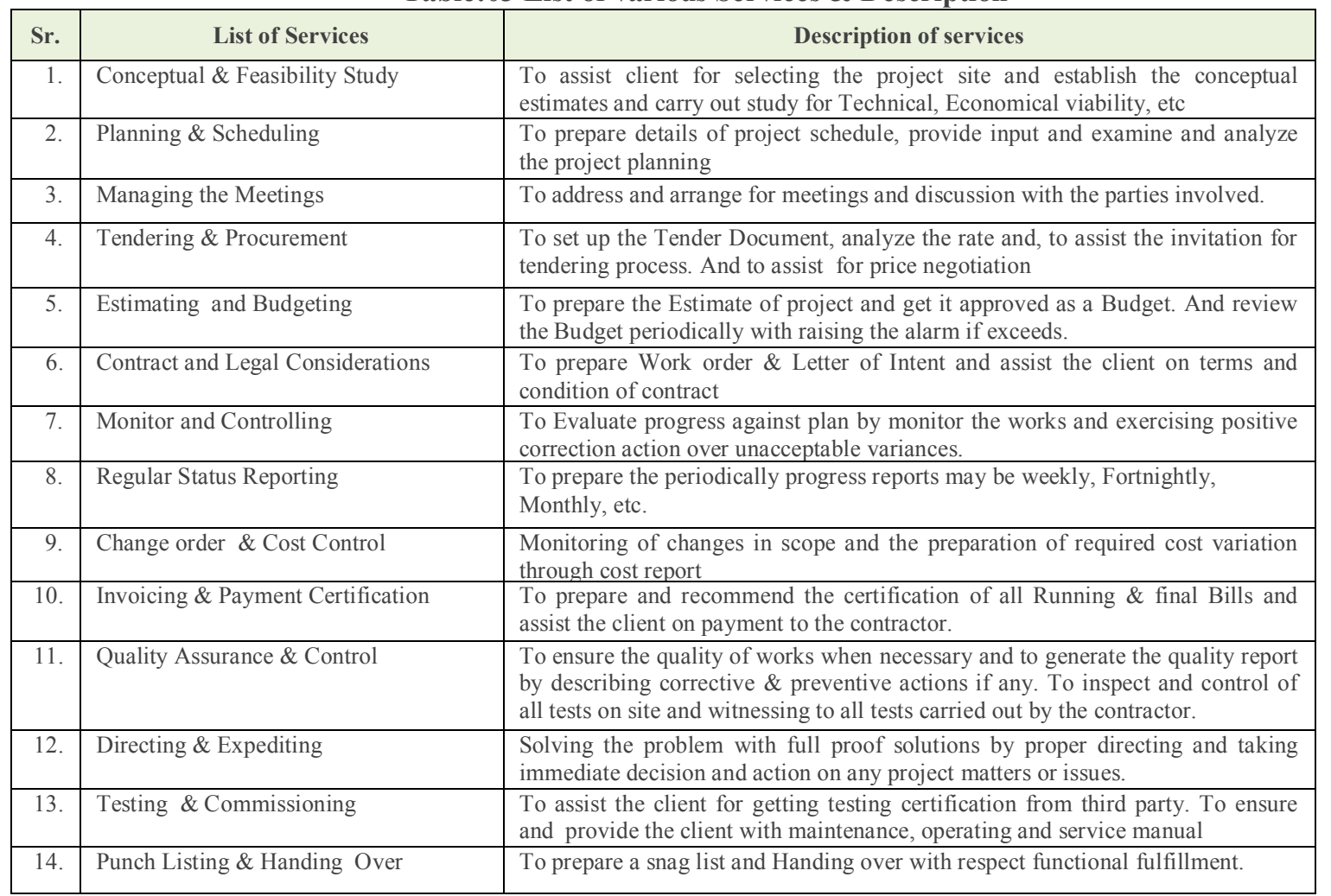

ii. Section A : Demographics:

Demographics include information of an organization, respondents and their positions

\section{ii.1. Which Organisation do you represent ?}

The respondents were asked to identify, from the list given, the organization that the respondent represents in order for the writer to classify the type of respondent. The results for question, shown in table 04 below: the profile of the respondents of the preliminary survey where majority (31\%) of the respondents were from Contractor firm. From the total number of respondents, Project Management Consultant Firms represent 29\%, Architects firms $17 \%$, while $24 \%$ were from Client. 
Table 04: Organization Representation.

\begin{tabular}{|c|c|c|c|c|}
\hline $\begin{array}{l}\text { Type of } \\
\text { respondent }\end{array}$ & Frequency & $\begin{array}{l}\text { Percentage } \\
(\%)\end{array}$ & $\begin{array}{c}\text { Cumulative } \\
\text { Percentage } \\
(\%)\end{array}$ & $\begin{array}{l}\text { Client / } \\
\text { Devepopers }\end{array}$ \\
\hline $\begin{array}{l}\text { Client / } \\
\text { Developers }\end{array}$ & 10 & 24 & 24 & \\
\hline $\begin{array}{l}\text { Project } \\
\text { management } \\
\text { consultancy }\end{array}$ & 12 & 28 & 52 & $\begin{array}{l}\text { Project } \\
\text { management } \\
\text { consultancy }\end{array}$ \\
\hline $\begin{array}{l}\text { Architect Firm } \\
\text { /Other } \\
\text { consultants }\end{array}$ & 7 & 17 & 69 & $\begin{array}{l}\text { Architect Firm } \\
\text { / Other } \\
\text { Consultant }\end{array}$ \\
\hline $\begin{array}{l}\text { Contractors } \\
\text { Representative }\end{array}$ & 13 & 31 & 100 & $\begin{array}{l}\text { Contractors } \\
\text { Representative }\end{array}$ \\
\hline Total $(\mathrm{N}=42)$ & 42 & 100 & 100 & \\
\hline
\end{tabular}

\section{ii.2. Position in the organization:}

The respondents were asked to identify, from the list given, the position that the respondent holds in the organization that the respondent represents. Table- 05 shows the types of respondent against their position in the company.

Table 05: Position in the Organization.

\begin{tabular}{|c|c|c|c|c|}
\hline $\begin{array}{c}\text { Type of } \\
\text { respondent }\end{array}$ & Frequency & $\begin{array}{l}\text { Percent } \\
\text { age (\%) }\end{array}$ & $\begin{array}{c}\text { Cumulative } \\
\text { percentage } \\
\%\end{array}$ & $\begin{array}{l}\text { Client } \\
\text { Representative }\end{array}$ \\
\hline $\begin{array}{c}\text { Client } \\
\text { Representative }\end{array}$ & 11 & 26 & 26 & \\
\hline $\begin{array}{l}\text { Project Manager } \\
\text { ( \& Above) }\end{array}$ & 8 & 19 & 45 & (and Above) \\
\hline $\begin{array}{l}\text { Architect /Other } \\
\text { consultant }\end{array}$ & 7 & 17 & 62 & $\begin{array}{l}\text { Architects } \\
\text { representative/ }\end{array}$ \\
\hline $\begin{array}{l}\text { Project Engineer } \\
\text { (\& below PM) }\end{array}$ & 16 & 38 & 100 & $\begin{array}{l}\text { Other Consultant } \\
\text { Project Engineer }\end{array}$ \\
\hline Total & 42 & 100 & 100 & (and below PM) \\
\hline
\end{tabular}

It was found that 19 percent of the respondents who hold project manager ( and above) position, while the project engineer (and below PM) represent 38\% in this questionnaire survey, and 17\% for the Architect contribute to this investigation, $26 \%$ from the respondents who hold the position of Clients and Client representative.

\section{ii.3. Number of construction project (In which you have involved )?}

Table 06 below shows that, the respondents have been involved in $1-5$ construction projects are 17 persons with the percentage of $41 \%$, for the respondent who have been involved in 5-10 construction projects they are 14 persons with the percentage of $33 \%$, and for the respondent who have been involved in more than 10 construction projects are 11 persons with the percentage of $26 \%$ with the high knowledge and experience, This shows that most of the respondents had multiple experiences in the construction industry.

Table 06: Types of respondent and number of projects involved.

\begin{tabular}{|c|c|c|c|c|c|c|c|}
\hline \multirow{2}{*}{$\begin{array}{c}\text { Respondent } \\
\text { position }\end{array}$} & \multicolumn{3}{|c|}{ Number of Construction } & \multirow[t]{2}{*}{ Total } & \multirow{2}{*}{$\begin{array}{l}\text { Percent } \\
\text { age }(\%)\end{array}$} & \multirow{8}{*}{$26 \%$} & \multirow{3}{*}{$1-5$ projects } \\
\hline & $\begin{array}{c}1-5 \\
\text { projects }\end{array}$ & $\begin{array}{c}5-10 \\
\text { projects }\end{array}$ & $\begin{array}{l}10 \& \\
\text { more }\end{array}$ & & & & \\
\hline Project Manager & 1 & 4 & 3 & 8 & 19 & & \\
\hline Project Engineer & 8 & 7 & 2 & 17 & 40 & & \multirow{5}{*}{ 5-10 projects } \\
\hline Architect & 0 & 2 & 5 & 7 & 17 & & \\
\hline $\begin{array}{l}\text { Client } \\
\text { representative }\end{array}$ & 8 & 1 & 1 & 10 & 24 & & \\
\hline Total & 17 & 14 & 11 & 42 & 100 & & \\
\hline Percentage (\%) & 41 & 33 & 26 & 100 & & & \\
\hline
\end{tabular}




\section{ii.4. Construction Projects done with PMC / Using PMC ?}

The respondents were asked to identify, from the list given, the number of projects that the respondents had carried out that employed the services of PMC. Table 07 shows that the number of 10 construction project which contribute 24 percent worked with Client, 12 construction project which contribute 29 percent worked with project management consultants, and the highest number of 13 construction projects which contribute 31 percent worked with contractors.

Only 17 percent of the respondents had used the services of PMC for 10 or more of their projects. The results show that most of the projects carried out by the respondents had used other methods of handling the projects i.e. traditional approaches where did not require any project management services.

Table 07: Types of respondent and number of projects using PMC services

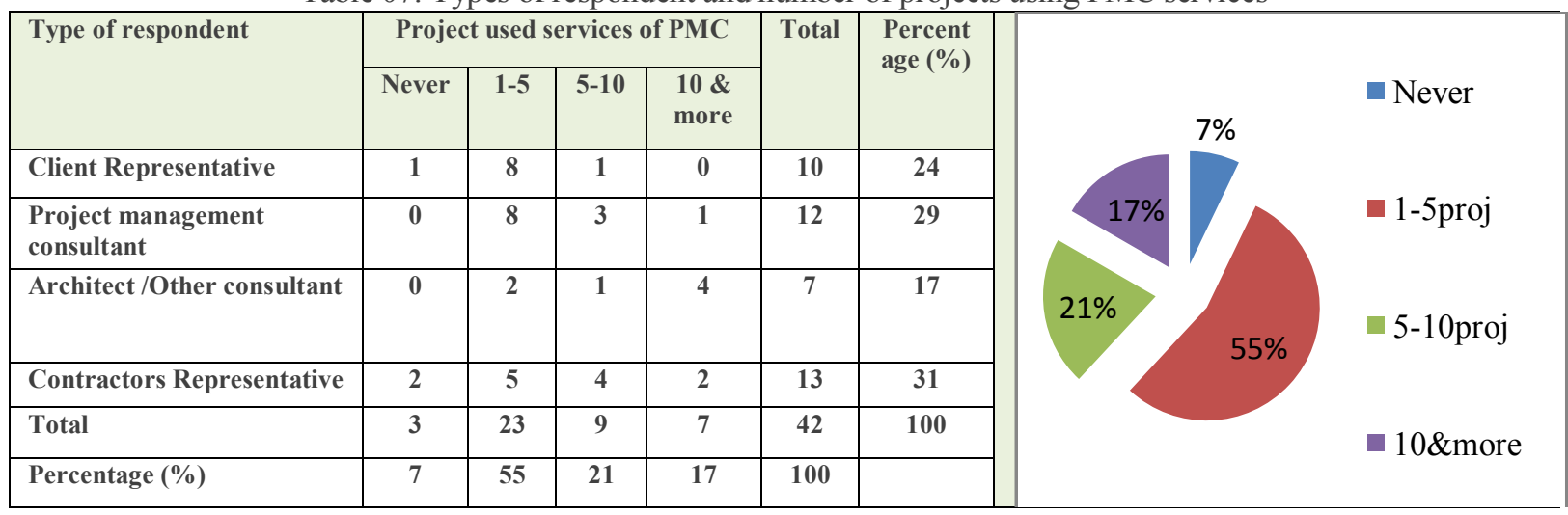

iii. $\quad$ Section B : Problems faced by PMC in implementing the project :

The summary of results of the survey based on Fig 02 for the problems faced by PMC in implementing the project show that most of the services listed by the author were regarded by the respondents as problems faced by PMC in implementing the project. the problems according to priority are :- slow decesion making by client,ambiguous project scope statement, unclear work procedure, and owners financial difficulties and delay in payments to vendors by client.

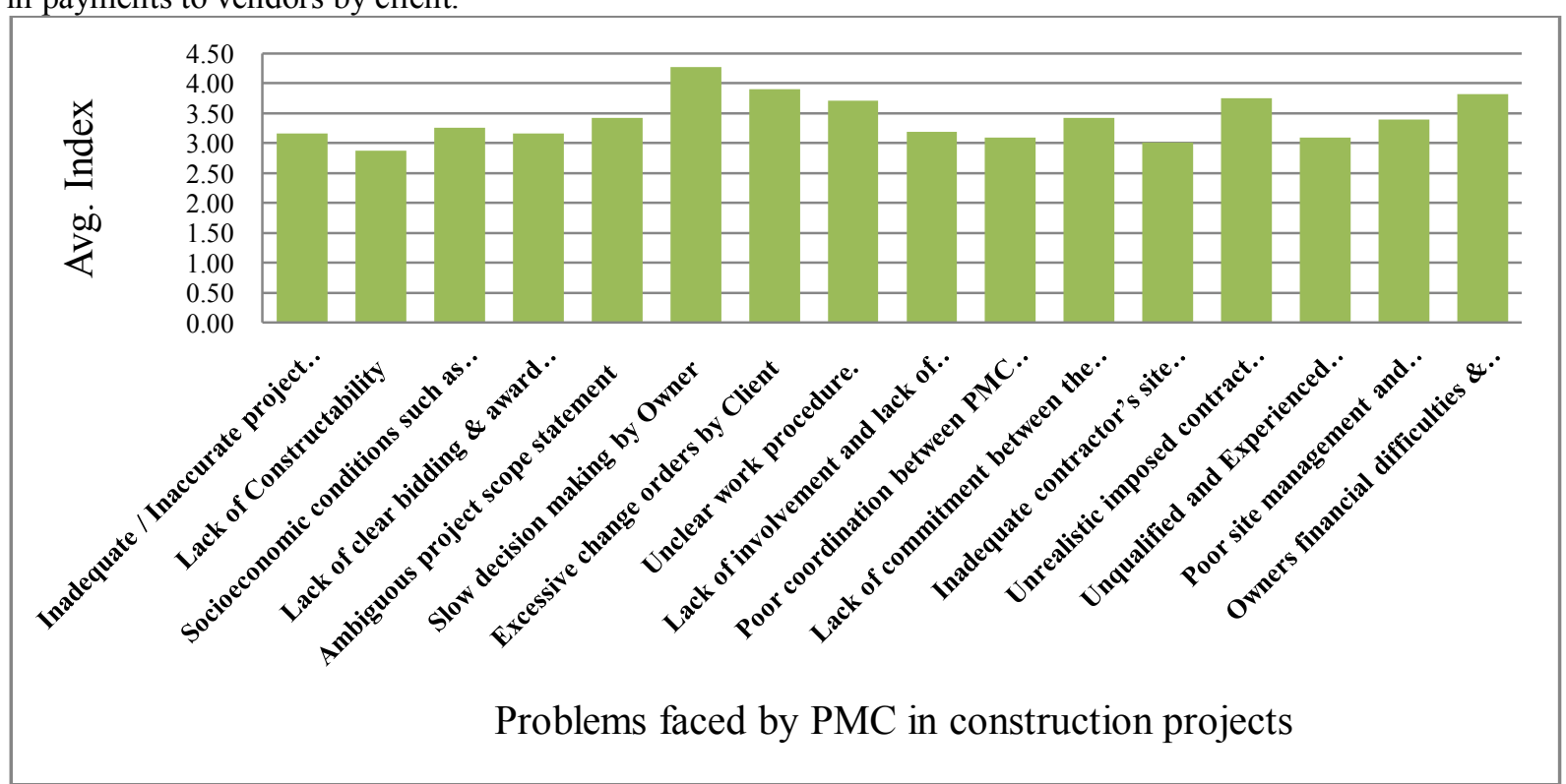

Fig-02 Problems Faced by PMC

iv. Section C : Auditing of Standard operating process regarding Services Provided by PMC :

Audit weightage 100, 50, \& 25 were decided by experts and as per requirement based on experience, From fig-03 it is clear that, submittal process has score of $35.71 \%$ and $81.82 \%$ for communication control process in concept $\&$ development phase and common phase respectively. Also addition to that change order process has $75 \%$ scored and $85.71 \%$ for vendor evalution in execution and transferring phase respectively. These figer state over all average score between $70-80 \%$ This score is up to satisfactory mark but still it needs to be improved by conducting frequent mock audit by monthly,cross Auditevery two months\& real auditquarterly in the year. 


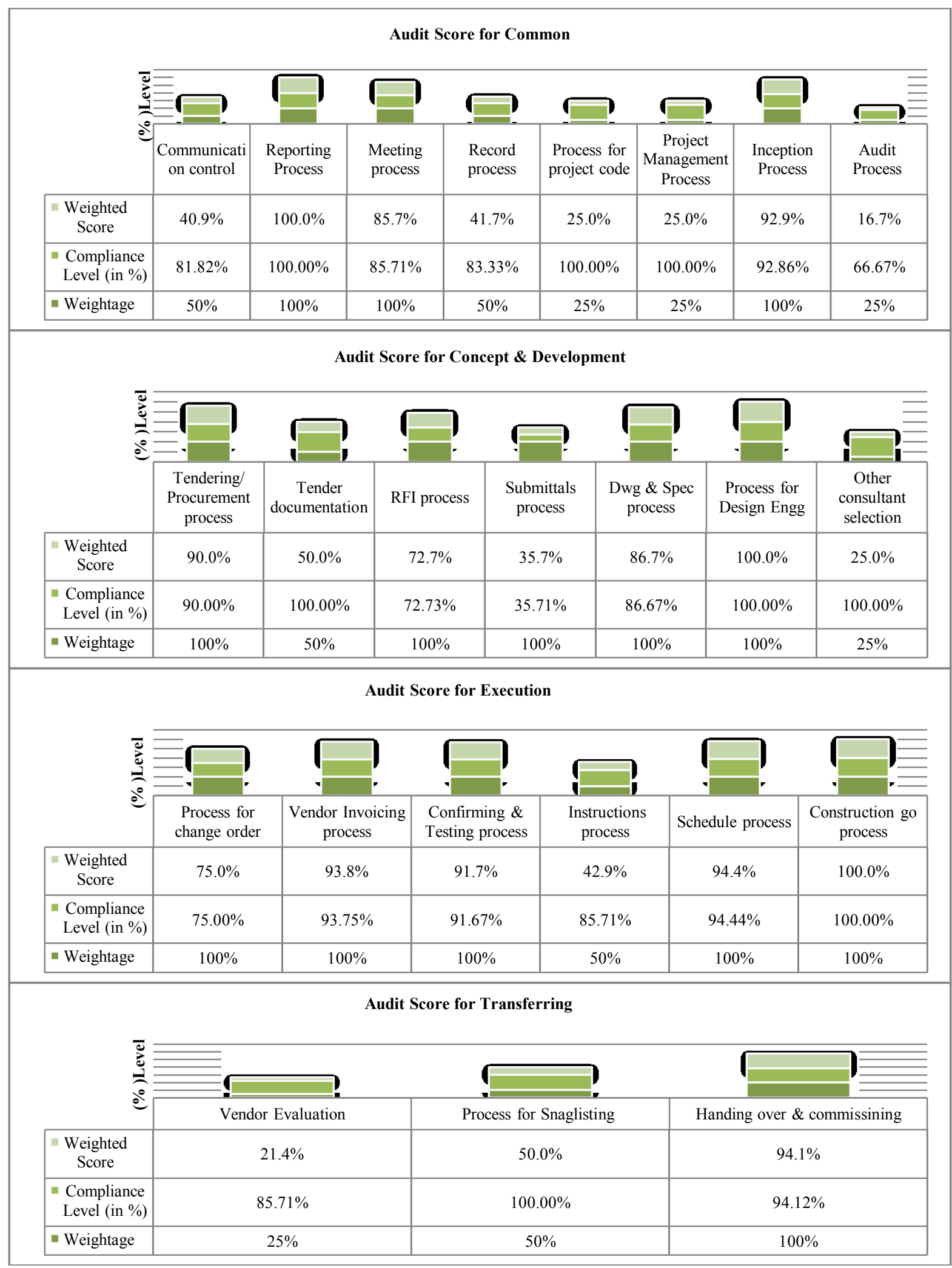

Fig- 3 - Phase wise audit descrition

\section{v. Section D : Degree of Importance of Services Provided by PMC :}

The respondents were asked to rate the degree of importance on the list of services provided by the PMC. In analyzing the data, the following assumed values have been considered for responses on the degree of importance of services that should be provided by Project management Consultant (PMC): "Not important" (1), "Less Important" (2), "Moderately Important" (3), "Important" (4), and "Very important" (5). The list provided 
was produced by the researcher from the case study carried out and was arranged and classified according to the research objective. The results presented in Fig.04 shows a list of services provided by PMC.

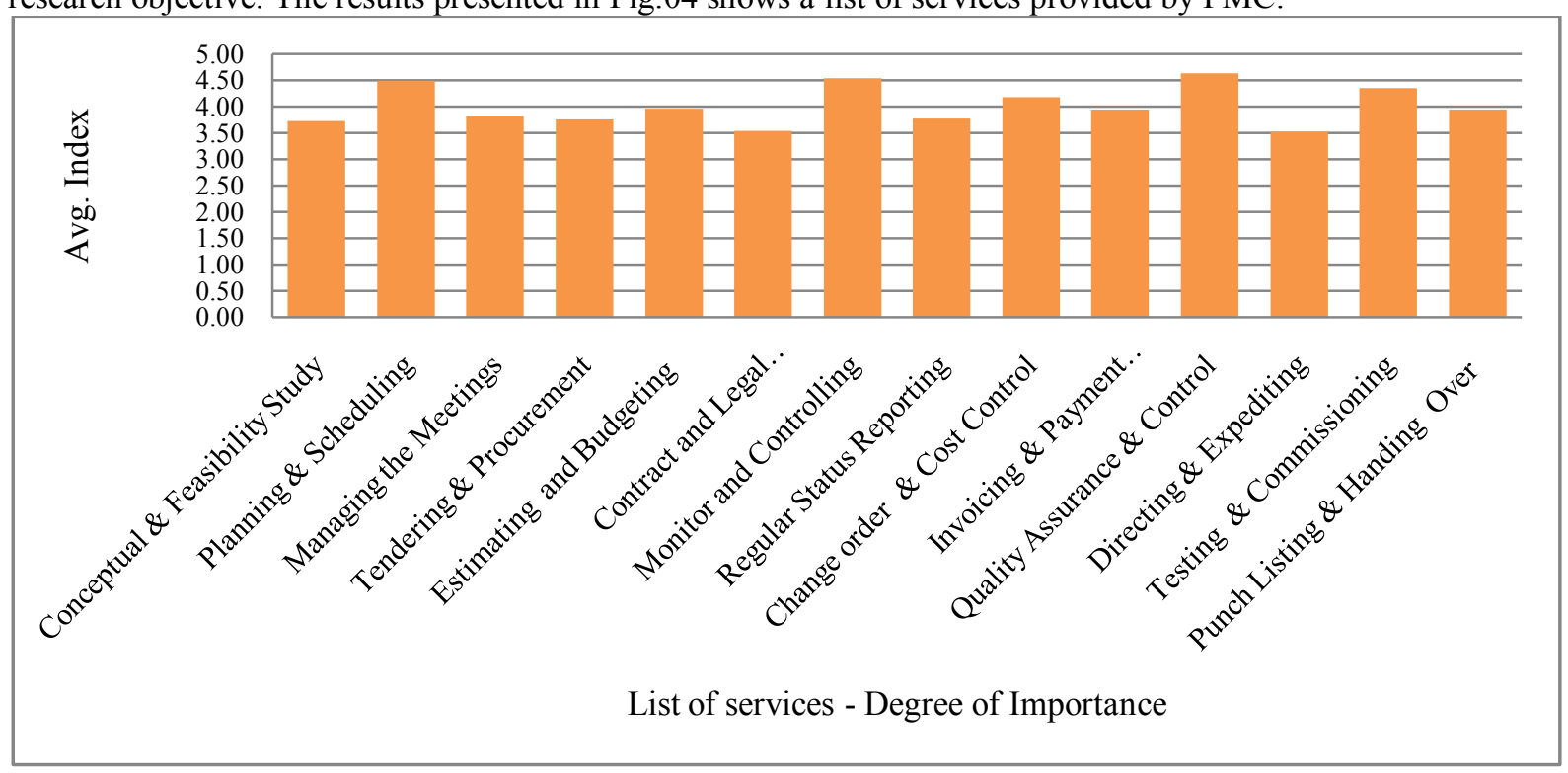

Fig-04 Degree of Importance of Services provided by PMC

\section{vi. Section E : Degree of Satisfaction of Services Provided by PMC :}

The respondents were asked to rate the degree of satisfaction on the list of services provided by the PMC. In analyzing the data, the following assumed values have been considered for responses on the degree of satisfaction on the services provided by Project management Consultant (PMC) which was marked as "Not satisfied" (1), "Less Satisfied" (2), "moderate" (3), "satisfied" (4), and "Very satisfied" (5). In figure 05, the list provided was produced based on the study carried out and according to the research objective. The results presented in Fig. 05 presents a list of services provided by PMC

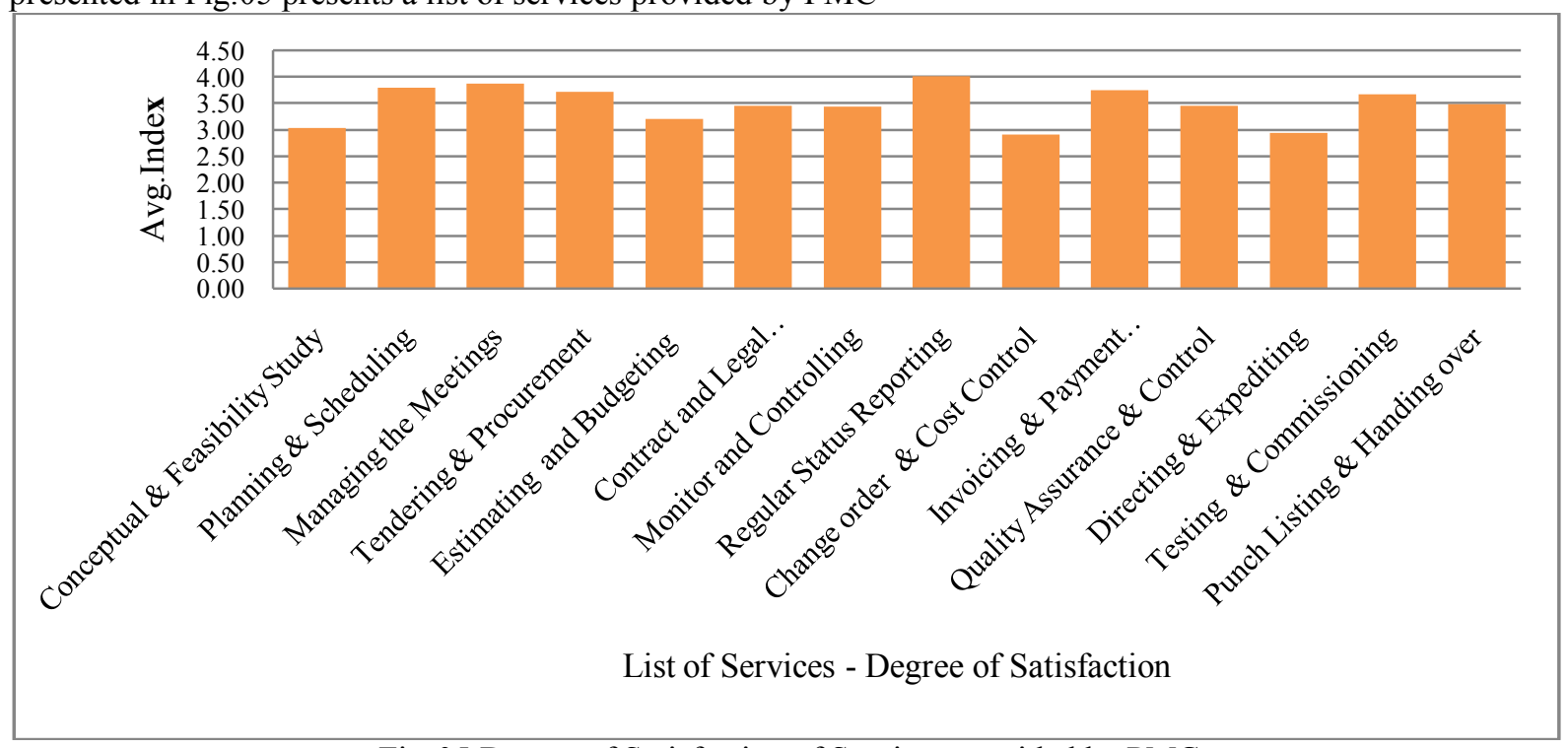

Fig-05 Degree of Satisfaction of Services provided by PMC

XV.

CONCLUSION:

A study on Role, Responsibility \& Services carried out by Project Management Consultant was conducted for Industrial Projects mostly. The study also focused on various problem faced by PMC and solution provided during services this study was not intended to be specific or limiting in scope but was intended to define what would normally be done in actual project management consultant. This study was primarily intended to serve as a guide to Project Management Consultant Firm in respect of the suggested scope and extent of services and also for the guidance of the clients who may wish to engage a PMC Firm offering project management services.

From the results of the survey on the problem faced by PMC, it can be concluded that the problems 
according to priority are as follows:

1. Inaccurate project feasibility studies and ambiguous project scope statement.

2. Slow decision making by client \& unrealistic imposed contract duration

3. Unclear work procedure \& excessive change order

Degree of Importance of services shows, only three services were considered by the respondents as very important which are Planning \& scheduling, Monitor\& Controlling, Quality assurance\& Control. The overall results are the various tabulated in figures as shown earlier.

Also during audit following area are required to be slight improved in order to control the construction projects through documentation more smoothly like , Communication control, Submittals \& Request for Information management, Change Control Procedures, Project Close-out and Completion,

Level of satisfaction on services provided by the PMC shows that the respondents have categorized the services provided by the Project Management Consultant which is " moderate satisfied"

\section{RECOMMENDATION:}

The selection of the project management consultant should not be based on the lowest quote in awarding the contract. The client should have a list of good Project Management Consultants who are experienced in carrying out the projects.

Construction Industry Boards like CIDC should monitor the Project Management Consultants and they should have a list of trustworthy consultants. By keeping records of the consultants, the CIDC should be able to advise the clients regarding the consultants in terms of their performance, and the number of projects at hand.

The Project Management Consultants should employ with experienced and trained staff and employee should apply their Skill, Knowledge and Experience also they should put the customers interest ahead of their profit.

\section{ACKNOWLEDGEMENT}

The authors would like to thank to Project Management Consultants and M/s client of Mega Industrial Project Pvt Ltd, India for their support and guidance in completing the research for the case study. The author also thankful to all respondents of PMC, Clients, Architect, \& Contracting firms for their valuable time and feedback during site visits.

\section{REFERENCES:}

[1] Cheung, S.-O.; Suen, H. C. H.; Cheung, K. K. W. 2004. PPMS: a Web-based construction project performance monitoring system, Automation in Construction 13: 361-376. doi:10.1016/j.autcon.2003.12.001.

[2] Dr. Dimitrios P. Kamsaris, Professor of Organizational Behavior,StefanosKougoulos, Doctorate Candidate, Project Management UGSM, Switzerland,Construction project management and the effects of project team cohesion-PM World Journal Construction Project Management andVol. I - Issue I - August 2012

[3] E.WilliamEast,AmrHassanein,johnmelin, Evaluating factors that affect construction project duration, USACERL technical report FF-92/09 sept 1992

[4] Foxhall, W. (1976). Professional construction Management and project administration. New York: Architectural Record and the American Institute of Architects.

[5] K KChitkara,(2000):Construction Project Management, Second Edition, Tata McGraw Hill Pvt Ltd. New Delhi.

[6] Project Management Institute, Inc. (2013):A Guide to Project Management Body of Knowledge, (PMBOK) Fifth Edition,Project Management Institute, Inc.Pennsylvania 19073-3299 USA

[7] P K Joy,(1994) :Total Project Management, Second Edition, Macmillan India Limited.New Delhi.

[8] Dzulkarnaen Ismail (2005), Services Provided by Project Management Consultant in Malaysian Construction Industry, MSc Thesis, Faculty of Civil Engineering, Universiti Teknologi Malaysia. 